\title{
Perkembangan Filsafat IImu serta Kaitannya dengan Teori Hukum
}

\author{
Oleh Sobirin Malian \\ Fakultas Hukum UCY \\ totalmedia publish@yahoo.co.id
}

\begin{abstract}
Filsafat ilmu merupakan cabang ilmu filsafat yang sangat berguna untuk menjelaskan apa tujuan ilmu bagi manusia. Secara garis besar, filsafat ilmu mengemukakan alasan yang mendasar mengapa pengetahuan diperlukan bagi keteraturan dalam hidup manusia. Dalam hubungannya dengan antara filsafat ilmu dan teori hukum saling berhubungan erat. Di satu sisi, filsafat ilmu adalah bisa digunakan sebagai bahan dasar pembuat teori hukum. Dalam hal ini, teori hukum memang sengaja dirancang untuk lebih bersifat aplikatif dan mampu mmenjawab persoalan keadilan di tengah-tengah masyarakat. Filsafat ilmu bisa menjadi dasar bagi suatu perenungan atau pemikiran secara ketat, secara mendalam tentang pertimbangan nilai-nilai di balik gejala-gejala hukum sebagaimana dapat diamati oleh pancaindera manusia mengenai perbuatan-perbuatan manusia dan kebiasaan-kebiasaan masyarakat. Mengingat objek filsafat ilmu adalah pengetahuan, maka masalah atau pertanyaan yang dibahas oleh filsafat ilmu itupun antara lain berkaitan dengan manfaat dari pengetahuan itu sendiri.
\end{abstract}

Kata kunci: Hukum, Filsafat, ilmu pengetahuan, manusia

\section{Pendahuluan}

Manusia mengembangkan seperangkat ilmu. Hal ini bersumber pada kenyataan bahwa ia memerlukannya. Karena manusia mau tak mau harus menentukan sendiri bagaimana ia bersikap terhadap prasyarat-prasyarat kehidupannya, dan karena seluruh realitas secara potensial memengaruhinya, ia sedemikian membutuhkan pengetahuan yang setepat-tepatnya dan selengkap-lengkapnya tentang seluruh realitas itu. la hanya dapat hidup dengan baik apabila ia menanggapi realitas itu sebagaimana adanya, dan untuk itu ia harus mengetahuinya.

Ketika manusia hidup berdampingan satu sama lain, maka berbagai kepentingan akan saling bertemu. Pertemuan kepentingan antara manusia yang satu dengan yang lain ini, tak jarang, menimbulkan pergesekan ataupun perselisihan. Perselisihan yang ditimbulkan bisa berakibat fatal, apabila tidak ada sebuah sarana untuk mendamaikannya. Perlu sebuah mediator atau fasilitator untuk mempertemukan dua buah kepentingan yang bergesekan tersebut. Tujuannya adalah agar manusia yang saling bersengketa (berselisih) tersebut sama-sama memperoleh keadilan. Langkah awal ini dipahami sebagai sebuah proses untuk menuju sebuah sistem (tatanan) hukum. Kenyataan ini menjadikan manusia mulai berpikir secara rasional. Di berbagai komunitas (masyarakat) adat, hal ini menjadi pemikiran yang cukup serius. Terbukti, kemudian mereka mengangkat pemangku (tetua) adat, yang biasanya mempunyai 'kelebihan' tertentu untuk 'menjembatani' berbagai persoalan yang ada. Dengan kondisi ini, tetua adat yang dipercaya oleh komunitasnya mulai menyusun pola kebijakan sebagai panduan untuk komunitas tersebut. Panduan tersebut berisikan aturan mengenai larangan, hukuman bagi yang melanggar larangan tersebut, serta bentuk-bentuk perjanjian lain yang sudah disepakati bersama. Proses inilah yang mengawali terjadinya konsep hukum di masyarakat.

Pada sisi yang lain, berkaitan dengan filsafat, terutama filsafat Barat muncul di Yunani semenjak kira-kira abad ke-7 SM. Filsafat muncul ketika orang-orang mulai berpikirpikir dan berdiskusiakan keadaanalam, dunia, danlingkungan di sekitarmereka dan tidakmenggantungkan 
diri kepada agama lagi untuk mencari jawaban atas pertanyaan-pertanyaan ini. Banyak yang bertanya-tanya mengapa filsafat muncul di Yunani dan tidak di daerah yang beradab lain kala itu seperti Babilonia, Yudea (Israel) atau Mesir. Jawabannya sederhana: di Yunani, tidak seperti di daerah lain-lainnya tidak ada kasta pendeta sehingga secara intelektual orang lebih bebas. Orang Yunani pertama yang bisa diberi gelar filosof ialah Thales dari Mileta, sekarang di pesisir barat Turki. Tetapi filosof-filosof Yunani yang terbesar tentu saja ialah: Socrates, Plato, dan Aristoteles. Socrates adalah guru Plato sedangkan Aristoteles adalah murid Plato. Bahkan ada yang berpendapat bahwa sejarah filsafat tidak lain hanyalah "komentar-komentar karya Plato belaka". Hal ini menunjukkan pengaruh Plato yang sangat besar pada sejarah filsafat.

\section{Analisa Dan Pembahasan}

Kata filsafat berasal dari bahasa Yunani, philosophia: philein artinya cinta, mencintai, philos pecinta, sophia kebijaksanaan atau hikmat. Jadi filsafat artinya cinta akan kebijaksanaan. Cinta artinya hasrat yang besar atau yang berkobar-kobar atau yang sungguh-sungguh. Kebijaksanaan artinya kebenaran sejati atau kebenaran yang sesungguhnya. Filsafat berarti hasrat atau keinginan yang sungguh akan kebenaran sejati. Demikian arti filsafat pada mulanya. Menurut dari asal katanya pengertian filsafat terdiri dari kata filos (philos) yang artinya cinta dan solfiah yang artinya kearifan/ kebijaksanaan. Filsafat berasal dari bahasa Yunani "Philosophia" yang mempunyai arti cinta akan kebijaksanaan/ kearifan. Sedangkan berfilsafat mempunyai pengertian berpikir secara mendalam tentang hakekat segala sesuatu dengan cara mencari makna yang paling mendalam/ makna sesungguhnya.

Filsafat beserta cabang-cabangnya secara sederhana terbagi menjadi tiga macam yang menjadi lahan kerja filsafat, yaitu ontologi, epistemologi dan aksiologi. Ketiga dari lahan garapan filsafat tersebut termuat dalam tiga pertanyaan dimana dalam ontologi bertanya tentang apa. Pertanyaan apa tersebut merupakan pertanyaan dasar dari sesuatu. Sedangkan dalam epistemologi, mengenalinya dengan menggunakan pertanyaan mengapa. Sedangkan untuk aksiologi merupakan kelanjutan dari dari epistemologi dengan menggunakan pertanyaan bagaimana. Pertanyaan bagaimana tersebut merupakan kelanjutan dari setelah mengetahui dan cara mengetahuinya diteruskan dengan bagaimanakah sikap kita selanjutnya.

Dalam konteks ontologis, filsafat akan berhubungan erat mengenai sifat (wujud) atau lebih sempit lagi sifat fenomena yang ingin kita ketahui. Dalam ilmu pengetahuan sosial Ontologi terutama berkaitan dengan sifat interaksi sosial. Ontologi adalah mengerjakan terjadinya pengetahuan dari sebuah gagasan kita tentang realitas. Bagi ilmu sosial ontologi memiliki keluasan eksistensi kemanusiaan. Dalam kontels epistimologi, merupakan cabang filsafat yang menyelidiki asal, sifat, metode, dan batasan pengetahuan manusia yang bersangkutan dengan kriteria bagi penilaian terhadap kebenaran dan kepalsuan. Epistemologi pada dasarnya adalah cara bagaimana pengetahuan disusun dari bahan yang diperoleh dalam prosesnya menggunakan metode ilmiah. Medode adalah tata cara dari suatu kegiatan berdasarkan perencanaan yang matang \& mapan, sistematis \& logis. Sedangkan konteks aksiologis lebih kepada yang berkaitan dengan nilai seperti etika, estetika, atau agama. Dengan kata lain, bahwa aksiologis, merupakan bidang kajian filosofis yang membahas value (nilai-nilai)

Filsafatmembawakepadapemahamandantindakan. Tujuan filsafatadalah mengumpulkan pengetahuan sebanyak mungkin, dan menerbitkan dan mengatur semuanya itu di dalam bentuk yang sistematis. Filsafat membawa kita kepada pemahaman dan pemahaman membawa kita kepada tindakan yang lebih layak. Keinginan kefilsafatan adalah pemikiran secara ketat. Filsafat merupakan suatu analisis secara hati-hati terhadap penalaran-penalaran suatu masalah dan penyusunan secara sengaja serta sistematis atas suatu sudut pandang yang menjadi dasar suatu tindakan. Perlu diingat bahwa kegiatan yang dinamakan kegiatan kefilsafatan itu sesungguhnya merupakan perenungan atau pemikiran. Pemikiran jenis ini berupa meragukan segala sesuatu, 
mengajukan pertanyaan, menghubungkan gagasan yang satu dengan yang lain, menanyakan "mengapa" dan mencari jawaban yang lebih baik dibandingkan dengan jawaban yang tersedia pada pandangan pertama. Filsafat sebagai perenungan mengusahakan kejelasan, keruntutan dan keadaan memadainya pengetahuan agar kita dapat mengetahui pemahaman.

Namun demikian perjalanan pemikiran filsafat ilmu dari sebuah keilmuan tidak dapat dipisahkan dari perkembangan jaman atau sosiokultural. Paradigma keilmuan mengalami perkembangan bahkan perdebatan pada tiap jamannya. Sebagai contoh perdebatan filosofis abad XII antara aliran empirisme Francis Bacon dengan aliran rasionalisme Rene Descartes. Bacon mengatakan bahwa sains modern harus bermula pada fakta-fakta empiris yang dapat diamati, sehingga teori dibuat berdasarkan generalisasi dari fakta-fakta tersebut (inductive hypothetic). Disatu sisi, Descartes mengemukakan sains harus mendasarkan diri pada pemikiran yang berorientasi pada rasio (logika) dan menekankan pentingnya peran akal. Meskipun kemudian muncul paradigma perbauran kedua aliran tersebut oleh Newton dengan ilmu eksaktanya yang menggabungkan metode hipotetiko deduktif dan eksperimental induktif. Artinya sains modern bukan sekedar rasional ataupun empiris melainkan pengetahuan rasional empiris (rasional objektif).

Sedangkan dalam dimensi kajian filsafat ilmu dikenal adanya;( Muchsin,2006)

1. Dimensi ontologis (hakekat ilmu)

Ontologi adalah hakikat yang Ada (being, sein) yang merupakan asumsi dasar bagi apa yang disebut sebagai kenyataan dan kebenaran. dalam perspektif ilmu, ontologi ilmu dapat dimaknai sebagai teori tentang wujud dalam perspektif objek materil ke-IImuan, konsepkonsep penting yang diasumsikan oleh ilmu ditelaah secara kritis dalam ontologi ilmu.

2. Dimensi epistomologis (cara mendapatkan pengetahuan)

Epistemologi derivasinya dari bahasa Yunani yang berarti teori ilmu pengetahuan. Epistemologi merupakan gabungan dua kalimat episteme, pengetahuan; dan logos, theory. Epistemologi adalah cabang ilmu filasafat yang menengarai masalah-masalah filosofikal yang mengitari teori ilmu pengetahuan. engan kata lain, epistemologi adalah bagian filsafat yang meneliti asal-usul, asumsi dasar, sifat-sifat, dan bagaimana memperoleh pengetahuan menjadi penentu penting dalam menentukan sebuah model filsafat. Dengan pengertian ini epistemologi tentu saja menentukan karakter pengetahuan, bahkan menentukan "kebenaran" seperti apa yang dianggap patut diterima dan apa yang patut ditolak. Aspek epistemologi adalah kebenaran fakta / kenyataan dari sudut pandang mengapa dan bagaimana fakta itu benar yang dapat diverifikasi atau dibuktikan kembali kebenarannya.

\section{Dimensi aksiologis (manfaat pengetahuan)}

Aksiologi (teori tentang nilai) sebagai filsafat yang membahas apa kegunaan ilmu pengetahuan manusia. Aksiologi menjawab, untuk apa pengetahuan yang berupa ilmu itu di pergunakan? Bagaimana kaitan antara cara penggunaan tersebut dengan kaidah-kaidah moral? Bagaimana penentuan objek yang ditelaah berdasarkan pilihan-pilihan moral? Bagaimana kaitan antara teknik prosedural yang merupakan operasionalisasi metode ilmiah dengan norma-norma moral?

Jika kita berbicara filsafat, kita seakan berada pada ranah yang sangat abstrak, dan filsafat hukum merupakan cabang dari filsafat, filsafat hukum mempunyai fungsi yang strategis dalam pembentukan hukum di Indonesia. Sekedar menyinggung konsep dalam Islam, bahwa Islam menilai hukum tidak hanya berlaku di dunia saja, akan tetapi juga di akhirat, karena putusan kebenaran, atau ketetapan sangsi, disamping berhubungan dengan manusia secara langsung, juga berhubungan dengan Allah SWT, maka manusia disamping ia mengadopsi hukum-hukum 
yang langsung, yaitu wahyu Tuhan yang berbentuk kitab suci, manusia dituntut untuk selalu mencari formula kebenaran yang berserakan dalam kehidupan masyarakat, manusia akan melihat dari kenyataan empiris sebagai bekal mengkaji secara mendalam, memberikan makna filosofis dengan mengetahui hakikat kebenaran yang hakiki (Muchsin,2006). Kaitannya dengan pembentukan hukum di Indonesia, setidaknya kita sadar bahwa hukum di bentuk karena pertimbangan keadilan (gerechtigkeit) disamping sebagai kepastian hukum (rechtssicherheit) dan kemanfaatan (zweckmassigkeit). (Darmodiharjo,2006)

Secara umum ada tiga hal yang dapat dipelajari dari hukum, yaitu :

1. Nilai-nilai hukum, seperti keadilan, ketertiban, kepastian hukum dan lain-lain,

2. Kaidah-kaidah hukum berupa kaidah yang tertulis maupun tidak tertulis, kaidah yang bersifat abstrak maupun nyata

3. Perilaku hukum atau dapat juga disebut kenyataan hukum atau peristiwa hukum. Secara umum, filsafat hukum mengkaji nilai-nilai hukum, sosiologi hukum, antropologi hukum, psikologi hukum, dan lain-lain serta mengkaji perilaku hukum. Dalam filsafat hukum, nilainilai yang dikajipun harus bersifat normatif. Ciri yang umum dari kaidah hukum ialah adanya legitimasi dan sanksi.

Ilmu hukum sebagai ilmu bertujuan untuk mencari kebenaran atau tepatnya keadilan yang benar. Untuk mencari keadilan yang benar itu maka ditentukanlah cara untuk mencarinya yang disebut metode. Kebenaran yang dapat dicapai oleh ilmu hukum ialah apabila disadari adanya penampakan dari obyek dan seraya menyadari pula arti dibelakang obyek tersebut. Secara hakekat, ilmu hukum berusaha untuk menampilkan hukum secara integral. Ilmu hukum akan mempunyai kewibawaan dan kekuatannya apabila bersifat integral dalam aspek ontologis, epistemologis dan aksiologis. Sebab itu yang diperlukan dalam ilmu hukum ialah sintesis dari metode-metode, sehingga ilmu hukum memiliki suatu metode yang mempunyai ciri khas. IImu hukum adalah suatu sistem. Sebagai suatu sistem, ilmu hukum harus merupakan suatu kebulatan dari seluruh komponen atau subsistem yang satu sama lainnya saling berhubungan.

IImu hukum bersifat dinamis. Ilmu hukum mempunyai peran dan fungsi yang khas dibanding dengan bidang-bidang hukum yang lain. Secara aksiologis, peran dan fungsi dari ilmu hukum antara lain seperti diuraikan dibawah ini;

1. Ilmu hukum berpengaruh dalam pembentukan hukum melalui penyusunan perundangundangan.

2. IImu hukum berpengaruh dalam praktek hukum atau pelaksanaan hukum.

3. IImu hukum berpengaruh dalam pendidikan hukum. Pendidikan hukum yang formal yakni di bangku sekolah dan yang informal di tengah masyarakat lewat media massa dan penyuluhanpenyuluhan sangat dipengaruhi oleh ilmu hukum.

4. Ilmu hukum akan berpengaruh atas perkembangan dari bidang-bidang yang lainnya. Dalam suatu sistem hukum yang berusaha untuk mengatur segala hal atau segala bidang, maka sistem seperti itu bersifat progressif dan interventif.

5. Ilmu hukum berusaha untuk mengadakan sistematisasi. Bahan-bahan yang tercerai berai disatukan dalam suatu susunan yang bersifat komprehensif. Hasil sistematisasi menyajikan informasi yang memudahkan.

Apa beda Filsafat ilmu dan Teori Hukum? Filsafat ilmu menekankan pembahasan sebagian besar dari sudut studi filsafat, dan oleh karena itu menekankan penelitian dan penyelidikan dari sudut tradisi filsafat. Sedangkan Teori Hukum cenderung kepada bentuk operasional berdasarkan legal academy, yang cenderung mengkonsentrasikan diri kepada rasionalisasi dan legitimasi 
dari legal doctrine seperti perbuatan melawan hukum dan kontrak. Tentu dalam pembahasan filsafat hukum nanti tidak dapat dihindarkan membicarakan Teori Hukum yang bersumber dari Filsafat Hukum. (Golding,2005)

Teori hukum sekadar memberikan deskripsi (informasi) yang positif teoritikal, sama sekali tidak melakukan penilaian normatif (baik -buruk). Teori hukum dengan demikian berfungsi untuk mengolah produk dari ilmu- ilmu lain yang juga berobjekkan hukum, lalu mengubahnya menjadi teknik hukum untuk kepentingan ilmu hukum. Oleh karena itu, seorang teoritisi hukum sebagai partisipan (medespeler) dalam pengembanan hukum wajib memahami perspektif para pengamat (toeschouwer) atas adanya dan berlakunya hukum. Di samping itu, teori hukum melakukan pembentukan, pengolahan, pengembangan, dan pemantapan (pembakuan) konsepkonsep yuridis. Sebagai disiplin hukum yang berada di antara tingkat abstraksi ilmu hukum dan filsafat hukum, maka teori hukum juga difungsikan untuk merumuskan pertanyaan-pertanyaan yang akan diajukan kepada filsafat hukum. Sebaliknya, jawaban-jawaban yang diberikan filsafat hukum merupakan porsi teori hukum untuk kembali mengolahnya secara deskriptif. Tingkat abstraksi yang paling tinggi adalah filsafat hukum. Ada dua pokok permasalahan yang menjadi fokus filsafat hukum, yaitu tentang landasan mengikat dari hukum dan kriteria keadilan menurut hukum (kaidah hukum positif dan sistem hukum secara keseluruhan). Dalam kegiatan merefleksi dwitunggal pertanyaan inti tersebut, ranah telaah filsafat hukum mencakup aneka persoalan. (Golding,2005)

Berdasarkan inti teori Von Savigny : semua hukum pada mulanya dibentuk dengan cara seperti yang dikatakan orang, hukum adat, dengan bahasa yang biasa tetapi tidak terlalu tepat, dibentuk yakni bahwa hukum itu mulai-mula dikembangkan oleh adat kebiasaan dan kepercayaan yang umum. Baru kemudian oleh yurisprudensi, jadi dimana-mana oleh kekuatan dalam yang bekerja diam, tidak oleh kehendak sewenang-wenang dalam pembuatan UU. Von Savigny menekankan bahwa setiap masyararakat mengembangkan hukum kebiasaanya sendiri, karena mempunyai bahasa, adat istiadat (termasuk kepercayaan) dan konstitusi yang khas. (Friedman,1994)

Filsafat mempersoalkan pertanyaan-pertanyaan yang bersifat dasar dari hukum. Pertanyaan-pertanyaan tentang "hakikat hukum", tentang "dasar-dasar bagi kekuataan mengikat dari hukum", merupakan contoh-contoh pertanyaan yang bersifat mendasar itu. Atas dasar yang demikian itu, filsafat hukum bisa dihadapkan kepada ilmu hukum positif. Sekalipun sama-sama menggarap bahan hukum, tetapi masing-masing mengambil sudut pandang pemahaman yang berbeda sama sekali. IImu hukum positif hanya berurusan dengan suatu tata hukum tertentu dan mempertanyakan konsistensi logis asas-asas, peraturan-peraturan, bidang-bidang serta sistem hukumnya sendiri. (Rahardjo,200)

Purnadi Purbacaraka \& Soerjono Soekanto menyebutkan sembilan arti hukum, yaitu : (Darmodiharjo,2006)

1. Ilmu pengetahuan, yaitu pengetahuan yang tersusun secara sistematis atas dasar kekuatan pemikiran.

2. Disiplin, yaitu suatu sistem ajaran tentang kenyataan atau gejala-gejala yang dihadapi.

3. Norma, yaitu pedoman atau patokan sikap tindak atau perilaku yang pantas atau diharapkan.

4. Tata Hukum, yaitu struktur dan proses perangkat norma-norma hukum yang berlaku pada suatu waktu dan tempat tertentu serta berbentuk tertulis.

5. Petugas, yakni pribadi-pribadi yang merupakan kalangan yang berhubungan erat dengan penegakan hukum (law enforcement officer). 
6. Keputusan Penguasa, yakni hasil proses diskresi.

7. Proses Pemerintahan, yaitu proses hubungan timbal balik antara unsur-unsur pokok dari sistem kenegaraan.

8. Sikap tindak ajeg atau perilaku yang teratur, yakni perilaku yang diulang-ulang dengan cara yang sama, yang bertujuan mencapai kedamaian.

9. Jalinan nilai-nilai, yaitu jalinan dari konsepsi-konsepsi abstrak tentang apa yang dianggap baik dan buruk.

Sedangkan kekuasaan dalam arti hak sebagai bagian dari pemahaman kekuasaan dalam aspek hukum merupakan hak-hak yang dapat diakui keberadaannya oleh hukum. Salmond misalnya, sebagaimana yang dikutip oleh Lili Rasjidi, yang berpendapat bahwa kekuasaan merupakan hak sebagai kepentingan yang diakui dan dilindungi oleh hukum. Sementara Allend menganggap hak sebagai suatu kekuasaan berdasarkan hukum, yang dengannya seorang dapat melaksanakan kepentingannya (the legally guaranteed power to realize an inferest). (Rasyidi,1988)

Sementara itu, Menurut Jean Jacques Rousseau, kekuasaan sebenarnya berasal dari teori social contract. Menurut teori ini, manusia itu berdaulat penuh atas dirinya. la memiliki hak-hak yang lahir dari dan atas dirinya sendiri. Kedaulatan orang yang satu tidak kurang, tetapi juga tidak lebih dari yang lain. Dalam situasi yang seperti itu tidak akan mungkin ada kemajuan, maka manusia itu serentak bersama-sama menyerahkan kedaulatan masing-masing kepada masyarakat, lalu pelaksana perintah-perintahnya ialah negara dan pemerintah. Namun demikian, kedaulatan (Hutahuruk,1978) yang ada ditangan negara tidaklah absolut. Pada sisi inilah, perlu adanya teori pembatasan kekuasaan yang bertujuan agar hukum tetap eksis.

Di samping teori social contract, masih banyak lagi teori-teoriyang menjelaskan kekuasaan negara dengan hukum sebagai koridor pembatasnya. Dalam perjalanannya teori-teori social contract, teori kekuasaan dan teori hukum terus berdialektika, yang kemudian menemukan jalan tengah, yang kemudian disebut sebagai teori trias politica. Teori yang dikemukakan oleh Montesqieu (1688-1755) adalah teori yang paling banyak diikuti. Menurut ajaran teori trias politica, kekuasaan negara terbagi ke dalam tiga cabang kekuasaan (separation des pouvoirs/ separation of power) yaitu: 1) kekuasaan legislatif; 2) kekuasaan eksekutif; dan 3) kekuasaan yudikatif. (Mulyosudarmo, 1997)

Patut disimak apa yang telah didefinisikan oleh Sudikno Mertokusumo. Menurutnya, hukum merupakan keseluruhan peraturan atau kaedah dalam kehidupan bersama; keseluruhan tentang tingkah laku yang berlaku dalam kehidupan bersama, yang dapat dilaksanakan pelaksanaannya dengan suatu sanksi. (Merto Kusumo,1986)

Fungsi hukum yang paling menarik adalah hukum dipandang sebagai realitas kodrati. Sebuah bagian dari sifat alami manusia yang senantiasa tertanamkan, tranpa bisa dielakkan dalam setiap perilaku manusia itu sendiri. Menurut logika seperti ini, maka hukum dipandang sebagai sebuah realitas yang sangat mendasar. Keadaan seperti itu harus dipandang sebagai sesuatu realitas kodrati yang internal, sudah tertanam di dalam sanubari yang merupakan bagian integral eksistensi manusia, dan yang karena itu pula niscaya sudah eksis sebelum perilaku hukum manusia diwujudkan di alam pengalaman yang nyata. Dalam posisi seperti itulah, hukum adalah pengarah atau pengontrol atau sebuah tolak ukur guna menilai benar salahnya setiap bentuk manusia. (Wignjosoebroto,2002)

Dalam perkembangan selanjutnya, hukum memerlukan sarana untuk bisa eksis di hadapan masyarakat. Tujuannya agar masyarakat mengetahui secara kasatmata apa yang dinamakan sebagai hukum. Ini artinya, hukum haruslah berdasarkan atas sebuah sarana 
untuk menampilkan norma hukum sehingga dapat ditangkap oleh masyarakat secara luas. (Rahardjo,2000)

Ada beberapa syarat agar hukum bisa ditangkap dan dimengerti secara luas oleh masyarakat;

1. Hukum tersusun atas serangkaian kata-kata yang membentuk suatu kalimat. Bahasa hukum bisa menjadi sebutan untuk rangkaian kata-kata hukum tersebut. (Rahardjo,lbid)

2. Hukum menggunakan pengertian atau konsep-konsep untuk menyatakan kehendaknya. Pengertian ini merupakan abstraksi dari barang-barang yang bersifat konkrit dan individual. (Rahardjo,lbid)

Sebagai sebuah sistem peraturan, hukum menciptakan kondisi dimana hukum adalah norma yang memberikan suatu konsekuensi yang jelas sebagai sebuah kelanjutan dilakukannya suatu perbuatan. Sistem di dalam peraturan hukum bisa bercirikan sebagai berikut: (Rahardjo,opcit)

1. Sistem sebagai sebuah jenis satuan, yang mempunyai tatanan tertentu. Tatanan ini merujuk pada suatu struktur yang tersusun dari bagian-bagian.

2. Sistem sebagai sebuah metode, rencana atau prosedur untuk melakukan sesuatu.

3. Sistem dianggap sebagai sebuah kesatuan yang bersifat kompleks, yang terdiri atas bagianbagian yang terhubung satu sama lain.

Dalam suatu pengertian yang lebih utuh, dapat dikatakan bahwa maksud dari hukum sebagai sebuah sistem peraturan adalah norma yang termaktub dalam berbagai susunan katakata, yang bertujuan untuk terbinanya keteraturan dalam masyarakat. Singkat kata, ada sebuah kejelasan dan sebuah pengertian dalam menjelaskan karakter antara hak dan kewajiban serta susunan pelanggaran dalam masyarakat. Sehingga, masyarakat mempunyai pedoman dalam menjalankan kehidupan selanjutnya. Pedoman tersebut menjadikan masyarakat mempunyai kepastian dalam mengikuti aturan hukum yang berlaku. Tanpa itu, masyarakat akan dihadapakan pada kenyataan bahwa tidak ada pegangan dalam menjalankan kehidupan bermasyarakat. Sudah barang tentu, aturan menjadi tidak pasti dan tidak ada obyektifitas dalam menilai apa yang seharusnya dilakukan oleh masyarakat.

Sistem peraturan diperlukan untuk mempertahankan proses-proses yang terjadi dalam masyarakat agar berjalan secara teratur. Keteraturan ini timbul atas dasar kesadaran masyarakat dalam menjalin hubungan dengan masyarakat yang lain. Dengan keadaan seperti ini, maka paling tidak masyarakat akan dengan mudah memenuhi kebutuhan-kebutuhan mendasar.

Setiap sistem sosial memerlukan usaha dan cara-cara untuk mempertahankannya. Oleh karena itu, seiring dengan adanya suatu sistem sosial, pada saat itu pula sistem tersebut mengembangkan cara-caranya sendiri untuk mempertahankan dirinya. Dengan kata lain, kebutuhan untuk mempertahankan diri, dan kemudian usaha-usaha yang dilakukan ke arah itu adalah inheren dengan sistem sosial itu sendiri. Usaha sistem sosial untuk mempertahankan dirinya inilah yang disebut sebagai pengendalian sosial. (Rahardjo,Opcit)

Pengendalian sosial diperlukan sebagai sebuah sarana untuk menyesuaikan kehendak masyarakat umum agar kehidupan tertata secara normal. Seperti dikatahui sebelumnya, kehendak masyarakat tidak selalu sama dan seimbang. Ada kalanya kehendak masyarakat menjadi sebuah batu sandungan bagi kelompok masyarakat yang lain. Ini artinya, terjadi perbenturan kepentingan antar anggota masyarakat yang satu dengan anggota masyarakat yang lain. 
Dalam sistem pengendalian sosial terdapat asumsi bahwa apabila alat pengendali berupa norma sosial telah cukup ampuh maka norma hukum sebagai pengendali menjadi berkurang fungsinya, sebaliknya apabila norma sosial semakin kurang peranannya maka norma hukum menjadi sangat pneting perananannya. Atas dasar dalil yang demikian itu harus ditambah pengertian bahwa apabila ternyata norma hukum tidak berjalan secara efektif, maka secara asumtif kewibawaan hukum akan merosot. (Purnomo,1992)

\section{Penutup}

Filsafat ilmu sangat penting peranannya terhadap penalaran manusia untuk membangun ilmu. Sebab, filsafat ilmu akan menyelidiki, menggali, dan menelusuri sedalam, sejauh, dan seluas mungkin semua tentang hakikat ilmu. Dalam hal ini, kita bisa mendapatkan gambaran bahwa filsafat ilmu merupakan akar dari semua ilmu dan pengetahuan. Filsafat ilmu merupakan telaah kefilsafatan yang ingin menjawab pertanyaan mengenai hakikat ilmu. Dengan demikian, filsafat ilmu sangatlah penting peranannya bagi pengembangan ilmu pengetahuan. Tentu juga, filsafat ilmu sangat bermanfaat bagi manusia untuk menjalani berbagai aspek kehidupan.

Fungsi filsafat ilmu adalah untuk memberikan landasan filosofik dalam memahami berbagi konsep dan teori sesuatu disiplin ilmu dan membekali kemampuan untuk membangun teori ilmiah. Selanjutnya dikatakan pula, bahwa filsafat ilmu tumbuh dalam dua fungsi, yaitu: sebagai confirmatory theories yaitu berupaya mendekripsikan relasi normatif antara hipotesis dengan evidensi dan theory of explanation, yakni berupaya menjelaskan berbagai fenomena kecil ataupun besar secara sederhana.

Hukum memiliki hubungan timbal balik dengan masyarakatnya, karena hukum itu sendiri merupakan sarana pengatur masyarakat dan bekerja di dalam masyarakat. Itulah sebabnya, hukum tidak terlepas dari gagasan-gagasan maupun pendapat-pendapat yang hidup di kalangan anggota masyarakat. Struktur masyarakat dapat menjadi penghambat sekaligus dapat memberikan sarana-sarana sosial, sehingga memungkinkan hukum dapat diterapkan sebaikbaiknya.

Di lain pihak, suatu sistem hukum tidak bisa berjalan sendirian. Proses saling mempengaruhi antara sistem hukum dengan sistem yang lain yang berada dalam kehidupan masyarakat terus berjalan secara berkelanjutan. Di satu sisi nampak seiring, namun di sisi yang lain, proses ini bisa jadi menggilas sistem yang lain. Yang patut dijadikan rujukan dan mendapat perhatian adalah mengenai adanya budaya yang mengitari kehidupan masyarakat.

Di satu sisi, sebuah kebiasaan betul-betul menjadi hukum apabila kebiasaan tersebut dirasakan sebagai kewajiban yang harus ditaati, karena adanya pengukuhan dari pimpinan masyarakat atau dalam masyarakat modern, karena adanya pendapat umum, yurisprudensi atau doktrin. Lambat laun, ketika hukum kebiasaan ini menjadi lebih terlembaga, maka hukum kebiasaan ini bisa menjadi hukum adat yang secara turun-temurun diwariskan secara arif kepada komunitas tertentu di masyarakat.

\section{Daftar Pustaka}

Baidlowi, Ahmad \& Imam Baehaqie (Penerjemah), Filsafat Politik Kajian Historis dari Zaman Yunani Kuno sampai Zaman Modern, Pustaka Pelajar, Yogyakarta,2002

Purnomo, Bambang, "Pembangunan Hukum dalam Perspektif Ketertiban Sosial", Moh. Busyro Muqoddas, Salman Luthan, Muh. Miftahuddin (ed), Politik Pembangunan Hukum Nasional, UII 
Press, Yogyakarta, 1992

Bruggink, Refleksi Tentang Hukum, Cet II, Citra Aditya Bakti, Bandung, 1999

Darmodiharjo, Darji, dan Shidarta, Pokok-pokok Filsafat Hukum (Apa dan Bagaimana Filsafat Hukum Indonesia), PT. Gramedia Pustaka Utama, Jakarta, Cetakan VI, Mei 2006

Djokosutono, Ilmu Hukum, Ghalia Indonesia, Jakarta, 1982.

E. Utreht, Pengantar Dalam Hukum Indonesia, Ichtiar, Jakarta, 1966

Suseno, Franz Magnis, Etika Politik Prinsip-prinsip Moral Dasar Kenegaraan Modern, Gramedia Pustaka Utama, Jakarta, 1999

McLeod, lan, Legal Theory, Palgrave Macmillan, London, 2003

Rasjidi, Lili, Dasar-dasar Filsafat Hukum, Rajawali Press, Jakarta, 1988

M. Hutaharuk, Asas-asas IImu Negara, Erlangga, Jakarta,1978

Golding, Martin P. and William A. Edmundson (Eds), Philosophy of Law and Legal Theory, Blackwell Publishing Ltd, Oxford, 2005

Muchsin, Ikhtisar Filsafat Hukum, Cet II, Badan Penerbit Iblam, Jakarta, 2006

Rahardjo, Satjipto, IImu Hukum, Citra Aditya Bakti, Bandung, 2000

Wignjosoebroto, Soetandyo, Hukum; Paradigma, Metode dan Dinamika Masalahnya, Lembaga Studi dan Advokasi Masyarakat (ELSAM) dan Perkumpulan untuk Pembaharuan Hukum Berbasis Masyarakat dan Ekologi, Jakarta, 2002

Mertokusumo, Sudikno, Mengenal Hukum Suatu Pengantar, Liberty, Yogyakarta, 1986,

Mulyosudarmo, Suwoto, Peralihan Kekuasaan Kajian Teoritis dan Yuridis terhadap Pidato Nawaksara, Gramedia, Jakarta, 1997

W. Friedmann, Teoridan Filsafat Hukum : Idealisme Filosofis dan Problema Keadilan, PT. RajaGrafindo Persada, Jakarta, 1994.

Malian, Sobirin, Ide-ide Besar: Sejarah Intelektual Amerika, UII Press, Yogyakarta, 2003. 